\title{
Atrial Fibrillation in Dengue Infection: A Self-limiting Phenomenon? (Two Case Reports)
}

\author{
Raymond Pranata ${ }^{1,2^{\star}}$, Wendy Wiharja ${ }^{1,3}$, Vito Damay ${ }^{1,4}$ \\ ${ }^{1}$ Faculty of Medicine, Universitas Pelita Harapan, Tangerang, Banten, Indonesia \\ 2Tabanan General Hospital, Tabanan, Bali, Indonesia \\ ${ }^{3}$ Krakatau Medica Hospital, Cilegon, Banten, Indonesia \\ ${ }^{4}$ Siloam Hospital Lippo Village, Tangerang, Banten, Indonesia
}

${ }^{*}$ Corresponding author:

Raymond Pranata, MD, - email: raymond pranata@hotmail.com

Faculty of Medicine, Universitas Pelita Harapan, Tangerang, Banten, Indonesia / Tabanan General Hospital, Tabanan, Bali, Indonesia, Jl. Siloam Lippo Karawaci, Binong, Curug, Bencongan, Kelapa Dua, Tangerang, Banten 15810/Jl. Pahlawan No.14, Delod Peken, Kec. Tabanan, Kabupaten Tabanan, Bali 82100

Manuscript submitted: December 12, 2017; Revised and accepted: May 1, 2018

\section{ABSTRACT}

Dengue fever (DF) is highly prevalent in Indonesia as evidenced by 129,650 cases in 2015. Atrial fibrillation (AF) in dengue is exceptionally rare and usually self-limiting with resolution after recovery of illness. The aim of this case report is to depict two patients with AF in DF which resolves spontaneously in one and persists after infection in the other. Case 1 was 50 years old male presented with fever since 4 days before admission. NS1 antigen and IgM anti-Dengue virus were positive. An electrocardiogram (ECG) showed AF with rapid ventricular response (AFRVR). Case 2 was 53 years old male presented with dyspnea and palpitations 1 hour before admission. Patient had fever since 5 days before admission. Laboratory exams showed leukopenia, thrombocytopenia and positive IgM anti-Dengue virus. An electrocardiogram showed AFRVR. Intravenous fluids (normal saline), paracetamol, and digoxin were administered in both patients. They were admitted for close monitoring. Pre-discharge ECG of Case 1 showed resolution of AF. However, in Case 2, AF persists in pre-discharge ECG. In conclusion, physicians should be aware that a potentially reversible atrial fibrillation might be caused by this infection. It should be ensured that in those persisting cases, they should not be dismissed as just an 'irreversible' AF and progress into full-blown heart failure.

Keywords: atrial fibrillation; dengue infection; electrocardiography; dengue fever; reversible; tropical infection

\section{INTISARI}

Demam berdarah dengue (DBD) memiliki prevalensi yang tinggi di Indonesia, yakni mencapai 129.650 kasus pada tahun 2015. Fibrilasi Atrium (FA) merupakan komplikasi dari DBD yang jarang terjadi, dan biasanya akan sembuh dengan sendirinya apabila pasien sembuh dari DBD. Laporan kasus ini bertujuan untuk memperlihatkan 2 kasus FA pada DBD yang sembuh dengan sendirinya dan menetap setelah pasien sembuh dari DBD. Kasus 1 adalah laki-laki, 50 tahun, datang dengan keluhan demam selama 4 hari. Hasil positif ditemukan pada tes serologi dengue (NS1 dan IgM anti-Dengue antibody). Hasil elektrokardiogram (EKG) yaitu AF dengan response ventrikel cepat (AFRVR). Kasus 2 adalah laki-laki, 53 tahun, datang dengan keluhan sesak dan palpitasi 1 jam SMRS. Pasien memiliki gejala demam sejak 5 hari yang lalu. Hasil laboratorium menunjukkan leukopenia, trombositopenia, dan positif IgM anti-Dengue. Hasil EKG menunjukkan AFRVR 100-120x/menit. Kedua pasien di diagnosis dengan DBD dan AFRVR. Infus cairan salin normal, paracetamol, dan digoxin diberikan pada kedua pasien. Kedua pasien dimonitoring ketat. Pada saat pasien selesai perawatan, pada kasus $1 \mathrm{EKG}$ menunjukkan AF menghilang, sedangkan pada kasus kedua AF tetap ada pada hasil EKG. Sebagai kesimpulan, tenaga kesehatan harus waspada dengan kemungkinan FA yang tidak menghilang setelah DBD remisi, dimana pada kasus FA yang persisten, maka pasien sebaiknya tidak dipulangkan dulu karena bisa berkembang menjadi penyakit gagal jantung. 


\section{INTRODUCTION}

Dengue fever (DF) is highly prevalent in Indonesia as evidenced by 129,650 cases in 2015. ${ }^{1}$ Electrocardiographic abnormalities resulting from dengue infection are common and have been reported to be in the range of $34-75 \%$, these includes sinus bradycardia, atrioventricular blocks, premature ventricular contractions, Sinoatrial node dysfunction and Atrial Fibrillation(AF). Atrial fibrillation in dengue is exceptionally rare and usually self-limiting with resolution after recovery of illness ${ }^{2-4}$. The aim of this case report is to depict two patients with AF in DF which resolves spontaneously in one and persists after infection in the other.

\section{CASE PRESENTATION}

Case 1: 50 years old male presented with fever since 4 days before admission. Associated symptoms were myalgia, blanching rashes on chest, and palpitation. There was no previous episode of palpitation, dyspnea, chest pain/ discomfort or syncope. Past medical history of hypertension was confirmed and he consumed amlodipine regularly. History of diabetes, cardiac, kidney or cerebral illness was denied.

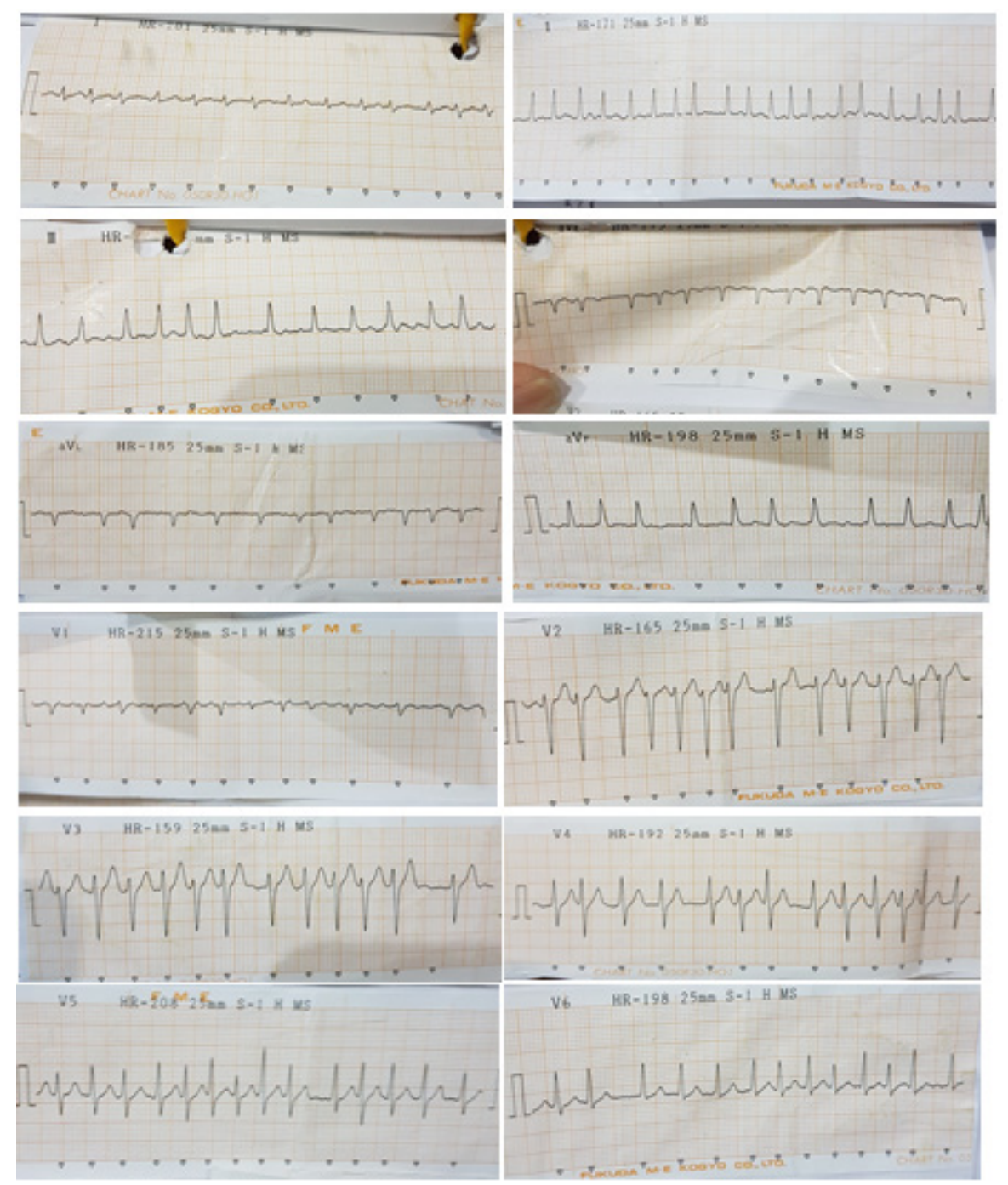

Figure 1. Electrocardiography recording of first case showing atrial fibrillation with rapid ventricular response (AFRVR) 
Physical examination showed blood pressure was $110 / 80 \mathrm{mmHg}$, irregularly irregular heart rate of $150 \mathrm{x} / \mathrm{min}$, respiratory rate of 22 $\mathrm{x} / \mathrm{min}$, temperature of $38.8^{\circ} \mathrm{C}$, cardiovascular and respiratory system examinations were within normal limits. Laboratory examinations revealed hemoglobin $14,9 \mathrm{~g} / \mathrm{dL}$, hematocrit $49,8 \%$, leukocyte count $4800 / \mathrm{mm}^{3}$, and thrombocytopenia $\left(65.000 / \mathrm{mm}^{3}\right)$. Renal function, electrolytes and coagulation profile were within normal limit. Peripheral blood film had no evidence of malarial parasite. NS1 antigen and IgM antibodies were positive for dengue virus. An electrocardiography (ECG) showed AF with Rapid Ventricular Response (AFRVR) (as shown in figure 1).

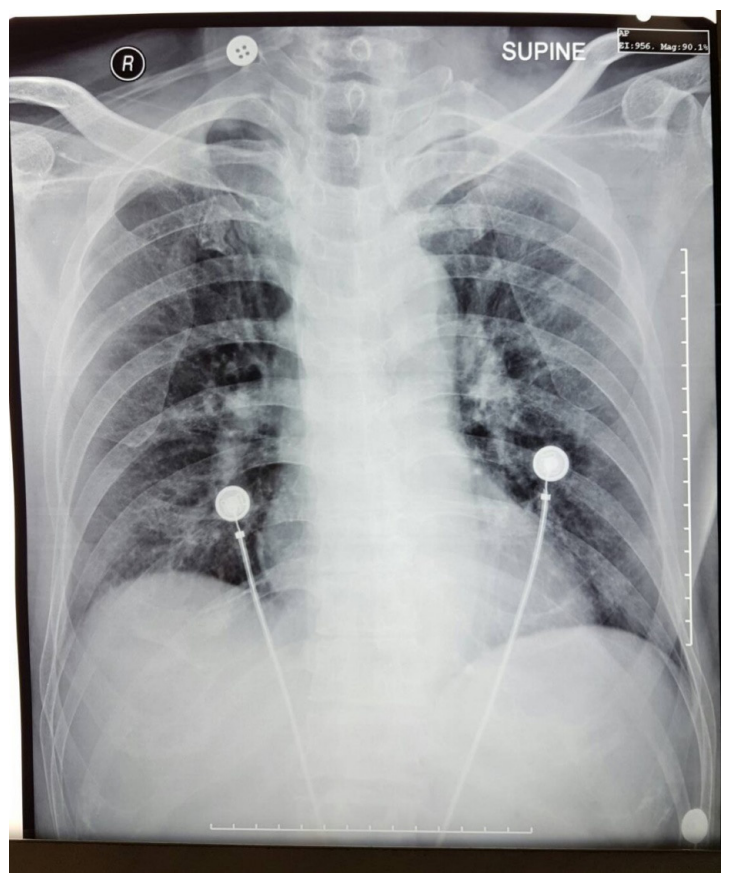

Figure 2. Chest X-Ray of first case showing no abnormalities

Chest x-ray showed no abnormalities (as shown in figure 2). Patient was diagnosed with dengue hemorrhagic fever (DHF) with AFRVR. Intravenous fluids (normal saline), paracetamol, and digoxin were administered. Patient was admitted for close monitoring. Patient was then discharged after 7 days and pre-discharge ECG showed resolution of AF becoming sinus rhythm (as shown in figure 3 ) .

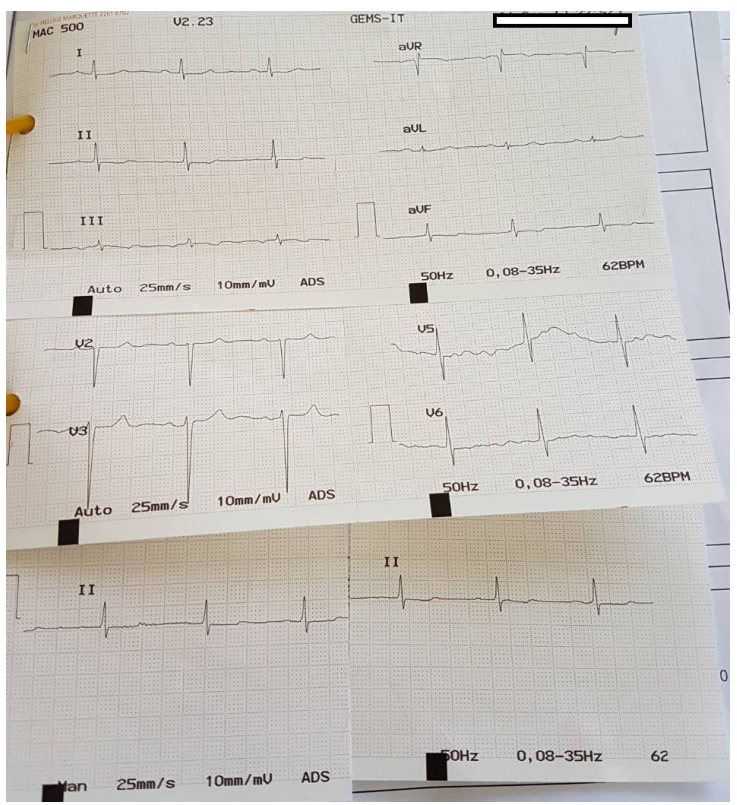

Figure 3. Pre-discharge electrocardiography recording of first case showing resolution of atrial fibrillation.

Case 2: 53 years old male presented with dyspnea and palpitations 1 hour before admission. Patient had fever since 5 days before admission. There was no previous episode of palpitation, dyspnea, chest pain/discomfort or syncope. Patient denied past medical history of hypertension, diabetes, cardiac, kidney or cerebral illness. Patient was neither smoker nor alcoholic. Blood pressure was $120 / 70 \mathrm{mmHg}$, irregularly-irregular heart rate of $110 \mathrm{x} / \mathrm{min}$, respiratory rate was $25 \mathrm{x} / \mathrm{min}$ and temperature of $39.5^{\circ} \mathrm{C}$. An ECG showed AFRVR $100-120 \mathrm{x} / \mathrm{min}$ (as shown in figure 4).

Laboratory examination showed leukopenia, thrombocytopenia and positive IgM antibody Anti-Dengue. Chest $\mathrm{x}$-ray was within normal limits (as shown in figure 5). Diagnosis of DF and AFRVR were established. Intravenous fluids (normal saline), paracetamol, and digoxin were administered. Patient was admitted for close monitoring. After 4 days hospitalization (3 days free of fever) patient was discharged and AF persisted. 


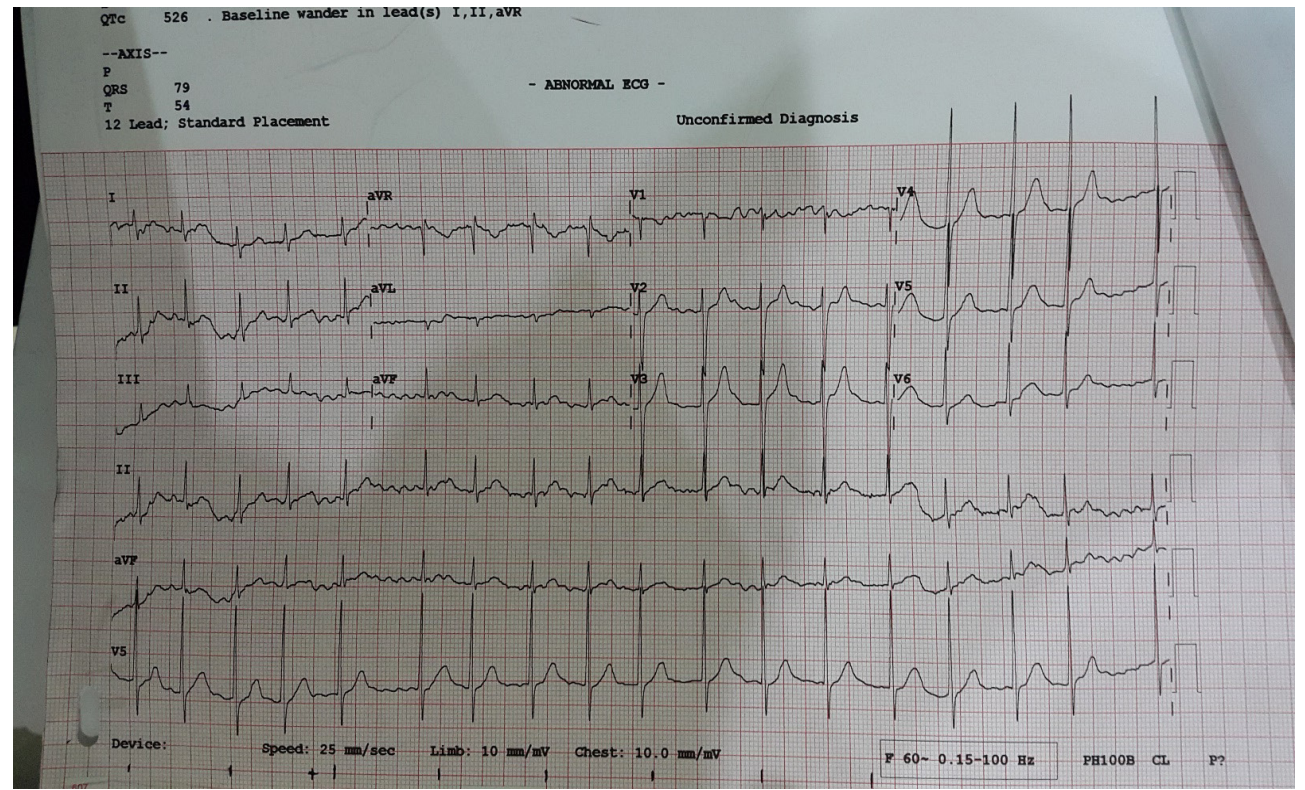

Figure 4. Electrocardiography recording of the second case showing atrial fibrillation with rapid ventricular response (AFRVR)

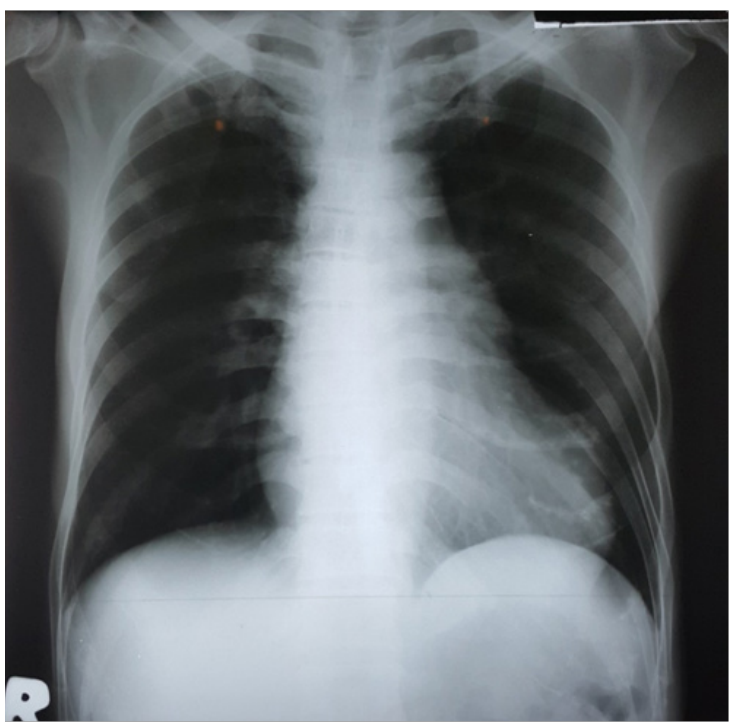

Figure 5. Chest X-Ray of second case showing no abnormalities

\section{DISCUSSION}

Dengue virus infection causes myocardial damage, either by direct invasion or an autoimmune reaction, which may result in myocarditis and may culminates into AF. A study by Salgado et al.(2010) explains that myocardial injury in dengue may be due to release of cytokine mediators and/or cellular components of the immune response. ${ }^{5}$
The patients with dengue hemorrhagic fever and dengue shock syndrome have higher level of TNF- $\alpha$, IL-6, IL-13 and IL-18, and cytotoxic factor which cause direct infection of cardiac muscle and trigger arrhythmias. Other hypothesis is altered contractility in dengue myocarditis secondary to increased resting intracellular calcium in the viral infected cardiac myocytes. ${ }^{5}$

The diagnosis of DHF in the first patient was confirmed by evidence of fever, rashes, thrombocytopenia, leucopenia, hemoconcentration, with positive serological tests. While diagnosis of DF in the second patient was established by the presence of fever, leucopenia, thrombocytopenia and positive serological test.

The possibility of AF in the first case was a consequence of DHF was established due to resolution of $\mathrm{AF}$ at the end of hospitalization period and the fact that patient had never experienced previous episode of palpitation, dyspnea or chest discomfort. It is less clear however, whether fever precipitated AF in the presence of hypertensive heart disease as a substrate, direct invasion or autoimmune 
reaction of dengue infection or a combination of them. No abnormalities on chest x-ray and no signs of left ventricular hypertrophy in the ECG suggested that there was no underlying hypertensive heart disease but still needs confirmation by echocardiography. The possibility of AF in the second case was due DF infection was strengthened by no apparent risk factors associated with $\mathrm{AF}$ in the patient and further reinforced by the fact that patient had never experienced previous episode of palpitation, dyspnea or chest discomfort.

Anticoagulant was not given in acute phase in both patients because of high risk of bleeding in DF and DHF. Digoxin was given as a rate control in both patients. Chemical cardioversion was not attempted, preferring observation, hoping spontaneous conversion into sinus rhythm after resolution of DF (may resolve in $50 \%$ of cases according to Bhatia et al) and avoiding potential embolization that may result from formation of thrombus in left atrium since onset of AF is unknown (may be $>48$ hours). ${ }^{2}$

Fortunately, AF spontaneously resolve in the first patient indicating that there was no further intervention needed besides a stricter control of blood pressure. However, in second case AF does not resolve by itself, anticoagulation should be continued 3 weeks after discharge with close follow-up whether the ECG persisted and needs cardioversion by direct current or chemical cardioversion to prevent complications arising from AF. It might not be always as 'self-limiting' as it thought to be.

\section{CONCLUSION}

Atrial fibrillation in dengue infection may or may not resolve spontaneously. It may be selflimiting in majority of patients but we have to be aware that it may potentially persist and cause cardiovascular complications. It is a substantial problem in a country with high prevalence of dengue infection. Physicians should be aware that a potentially reversible atrial fibrillation might be caused by this infection. It should be ensured that in those persisting cases, they should not be dismissed as just an 'irreversible' AF and progress into full-blown heart failure. This is especially a problem in rural areas where resources are scarce and access to specialized health care is a luxury.

\section{DECLARATIONS}

Ethics Approval: Not Applicable. Availability of data and material: The datasets supporting the conclusions of this article are included within the article. Competing interests: The authors declare that they have no competing interests. Funding: No source of funding

\section{REFERENCES}

1. Indonesian Ministry of Health. 2016. Profilkesehatan Indonesia tahun 2015 (2015 Indonesia Health Profile). Jakarta. Kementerian Kesehatan RI.

2. Bhatia V., ParidaA.K., Arora P., Mittal A., Pandey A.K., Singh G. et al. 2007. Electrocardiographic and echocardiographic findings during the recent outbreak of viral fever in National Capital Region. Indian Heart J, 59:360-362.

3. Yusoff K., Roslawati J., Sinniah M., Khalid B. 1993. Electrocardiographic and echocardiographic changes during the acute phase of dengue infection in adults. J HK Coll Cardiol, 1:93-96.

4. Lee I.K., Lee W.H., Liu J.W., Yang K.D. 2010. Acute myocarditis in dengue Haemorrhagic fever: a case report and review of cardiac complications in dengue-affected patients. Int J Infect Dis, 14:919-922.

5. Salgado D.M., Eltit J.M., Mansfield K., Panqueba C., Castro D., Vega M.R., et al. 2010. Heart and skeletal muscle are targets of dengue virus infection. Pediatr Infect Dis J, 29:238-42. 